\title{
PROGRAM PENDAMPINGAN PENINGKATAN LITERASI LEMBAGA KEUANGAN SYARIAH PADA MASYARAKAT DESA HONGGOSOCO
}

\author{
${ }^{1)}$ Faridhatun Faidah, ${ }^{2)}$ Gilang Puspita Rini, ${ }^{3)}$ Etni Marliana \\ Program Studi Manajemen, Fakultas Ekonomi dan Bisnis, Universitas Muria Kudus \\ Email: 1) faridhatun.faidah@umk.ac.id, ${ }^{2)}$ gilang.puspita@umk.ac.id, ${ }^{3)}$ etni.marliana@umk.ac.id
}

\begin{abstract}
Abstrak
Industri keuangan saat ini berinovasi dengan cepat, berbagai layanan yang diberikan oleh lembaga keuangan memiliki kelebihan dan kekurangan yang terkadang belum dipahami oleh masyarakat. Saat ini lembaga keuangan selain menyediakan lembaga keuangan konvensional juga menyediakan lembaga keuangan syariah. Perbedaan dari kedua lembaga keuangan tersebut terletak pada pengelolaan yang berbasis syariah dan konvensional. Salah satu lembaga keuangan syariah yang sedang berkembang pesat adalah perbankan syariah. Pemahaman masyarakat mengenai berbagai akad dalam perbankan syariah perlu diperjelas dengan memberikan contoh yang mudah dipahami bagi masyarakat, baik dari lapisan masyarakat atas atau bahkan menengah kebawah. Tujuan dari pengabdian ini adalah untuk memberikan literasi keuangan kepada masyarakat di Desa Honggosoco terhadap produk perbankan syariah yang tersedia di berbagai bank syariah di Indonesia. Setelah melakukan pengabdian ini diharapkan masyarakat Desa Honggosoco dapat lebih memahami berbagai akad dan layanan perbankan syariah.
\end{abstract}

Kata Kunci : lembaga keuangan konvensional, lembaga keuangan syariah, perbankan syariah.

\section{Abstract}

The financial industry is currently innovating rapidly, various services provided by financial institutions have advantages and disadvantages that are sometimes not understood by the public. At present financial institutions in addition to providing conventional financial institutions also provide Islamic financial institutions. The difference between the two financial institutions lies in sharia-based and conventional management. One sharia financial institution that is growing rapidly is Islamic banking. Public understanding of various contracts in Islamic banking needs to be clarified by providing examples that are easily understood by the public, both from the upper middle class or even lower. The purpose of this dedication is to provide financial literacy to the people of Honggosoco Village for Islamic banking products available in various Islamic banks in Indonesia. After doing this service, it is hoped that the people of Honggosoco Village will be able to better understand various Islamic banking agreements and services.

Keyword: conventional financial institutions, Islamic financial institutions, Islamic banking.

\section{PENDAHULUAN}

Perkembangan pergerakan keuangan syariah di Indonesia masih sangat lambat. Survei Nasional yang dilakukan Otoritas Jasa Keuangan (OJK) pada tahun 2016 menunjukkan tingkat literasi (pemahaman) dan tingkat inklusi (pemanfaatan) masyarakat tentang produk dan jasa keuangan syariah masih rendah. Hal terlihat dari indeks literasi keuangan syariah baru mencapai sebesar $8,11 \%$ dan indeks inklusi keuangan syariah sebesar $11,06 \%$. Sementara indeks literasi keuangan konvensional mencapai $29,66 \%$ dan indeks inklusi keuangan sebesar $67,82 \%$. Perbandingan yang masih sangat besar ini menjadi tugas bagi pemerintah untuk dapat meningkatkan literasi atau pemahaman kepada masyarakat terhadap produk dan jasa di lembaga keuangan syariah yang ada di Indonesia. Apalagi mengingat masyarakat Indonesia yang mayoritas beragama 
Islam, maka seharusnya industri keuangan syariah perlu digencarkan sebaik mungkin.

Apabila dilihat dari jenis sektoral, tingkat literasi dan inklusi pada perbankan syariah masih sebesar $6,63 \%$ dan 9,61\%, Asuransi Syariah sebesar $2,51 \%$ dan $1,92 \%$, pegadaian Syariah $1,63 \%$ dan $0,71 \%$, sementara itu untuk lembaga pembiayaan syariah, pasar modal syariah dan dana pensiun syariah nilai persentase tingkat literasi dan inklusinya masih di bawah 1\%. Hal ini menunjukkan bahwa masyarakat sudah mulai menggunakan produk perbankan dan keuangan syariah, namun belum banyak yang paham mengenai produk perbankan dan keuangan syariah. Istilah-istilah tentang perbankan syariah masih sulit dikenali oleh masyarakat umum. Hal inilah merupakan salah satu faktor penyebab rendahnya literasi keuangan syariah. Oleh karena itu, untuk meningkatkan perkembangan perekonomian syariah, perlu adanya peningkatkan aktivitas literasi dan inklusi keuangan syariah apalagi mengingat Indonesia merupakan salah satu negara yang memiliki potensi untuk meningkatkan pertumbuhan dan manfaat yang besar bagi industri Keuangan Syariah.

Potensi pertumbuhan lembaga keuangan syariah di Indonesia ini juga terlihat dari total aset keuangan syariah Indonesia (tidak termasuk saham) yang mencapai $\mathrm{Rp} 1.335,41$ triliun atau sebesar USD 94,44 miliar pada Juni 2019. Data tersebut diambil dari snapshot perbankan syariah yang dipublikasikan oleh Otoritas Jasa Keuangan (OJK). Pertumbuhan aset keuangan ini juga terus mengalami kenaikan dari tahun ke tahun. Asset terbesar ada pada sektor pasar modal syariah yaitu sebesar 734,01 triliun kemudian perbankan syariah 499,34 triliun dan disusul IKNB Syariah sebesar 102,06 triliun. Jawa tengah berada pada urutan nilai aset terbesar ke 4 di Indonesia. Posisi ini menjadi penting untuk diperhatikan karena mampu menjadi peluang bagi Indonesia agar mampu bersaing dan memajukan industri keuangan syariah tidak hanya di dalam Negara sendiri tetapi juga bersaing secara global manjadi pusat dari perekonomian Syariah di dunia.

Bank menjadi lembaga keuangan yang sering kali digunakan oleh masyarakat secara umum dalam melakukan transaksi tabungan dan juga pinjaman menjadi penting untuk terlebih dulu diketahui oleh masyarakat baik dari sisi kelembagaan, produk dan juga jasa yang ditawarkan. Dalam hal ini keberadaan bank syariah di Indonesia yang saat ini masih kalah jauh dengan bank konvensional menjadi perhatian khusuh untuk dapat meningkatkan kepercayaan masyarakat yang masih terbatas terhadap perbedaan yang dimiliki oleh lembaga tersebut. Dilihat dari data OJK tahun 2019 jumlah bank umum syariah di Indonesia masih sebanyak 13, unit usaha syariah sebanyak 21 dan BPRS sebanyak 167. Jumlah ini masih sangat sedikit dibandingkan jumlah bank konvensional yang ada di Indonesia. Masyarakat membutuhkan kemudahan dalam bertransaksi dan itu diwujudkan dengan keberadaan kantor dan fasilitas yang mampu disediakan oleh pihak bank, namun apabila kita lihat dari jumlah kantor bank syariah saat ini di Indonesia masih sangat terbatas. Data tersebut dapat dilihat pada tabel 1 .

Pengembangan ekonomi syariah harus betul-betul bermanfaat bagi hal-hal yang produktif, termasuk mendukung upaya penanggulangan kemiskinan dalam rangka menekan angka ketimpangan. Penggunaan pembiayaan syariah adalah 41,8 persen. Sebagian besar masih digunakan untuk konsumsi. Sedangkan pembiayaan untuk modal kerja dan investasi masing-masing baru mencapai 34,3 persen dan 23,2 persen. Hal ini menunjukkan bahwa masyarakat belum mengenal banyak tentang produk dan jasa yang ditawarkan oleh lembaga keuangan syariah. Sehingga perlu adanya sosialisasi peningkatan pemahaman masyarakat terkait produk dan jasa di lembaga keuangan syariah khususnya di Bank syariah yang mempunyai banyak istilah akad berbahasa arab. Sosialisasi ini lebih ditujukan kepada msyarakat pedesaaan dikarenakan menurut survei OJK pada tahun 2019 ini berdasarkan strata wilayah, untuk perkotaan indeks literasi keuangan mencapai $41,41 \%$ dan inklusi keuangan masyarakat perkotaan sebesar $83,60 \%$, sementara indeks literasi dan inklusi keuangan masyarakat perdesaan adalah $34,53 \%$ dan $68,49 \%$. Hasil survei ini juga menunjukkan bahwa berdasarkan gender indeks literasi dan inklusi keuangan lakilaki sebesar $39,94 \%$ dan $77,24 \%$, relatif lebih tinggi dibanding perempuan sebesar $36,13 \%$ dan 
75,15\%. Sehingga sosialisasi yang akan kami berikan akan terfokus pada masyarakat pedesaan yang menargetkan para ibu-ibu muda atau wanita karir yang ada di Desa Honggosoco dan terkumpul pada kelompok organisasi mayarakat yakni Fatayat NU.

Tabel 1. Jumlah Bank Syariah di Indonesia tahun 2013-2017

\begin{tabular}{lcccccc} 
& & 2013 & 2017 \\
\hline KELOMPOK BANK & 11 & 12 & 12 & 13 & 13 & 1.825 \\
\hline Bank Umum Syariah (Jumlah Bank) & 1.998 & 2.151 & 1.990 & 1.869 & 2015 \\
\hline Jumlah Kantor BUS & 2.092 & 2.160 & 2.175 & 2.655 & 3.026 \\
\hline Layanan Syariah Bank (LSB) & 23 & 22 & 22 & 21 & 21 \\
\hline Unit Usaha Syariah & 590 & 320 & 311 & 332 & 344 \\
\hline Jumlah Kantor UUS & 1.267 & 1.787 & 2.009 & 2.567 & 2.624 \\
\hline Layanan Syariah (LS) & 163 & 163 & 163 & 166 & 167 \\
\hline BPRS & 402 & 439 & 446 & 453 & 441 \\
\hline Jumlah Kantor BPRS & 2.990 & 2.910 & 2.747 & 2.654 & 2.610
\end{tabular}

Sumber : Otoritas Jasa Keuangan (OJK) Tahun 2018

Fatayat NU di Desa Honggosoco ini terdiri dari 56 anggota yang semuanya berjenis kelamin perempuan dan berumur kisaran $20-35$ tahun. Kebanyakan dari mereka bekerja sebagai guru dan buruh pabrik. Rata-rata tingkat pendidikan mereka adalah SMA dan beberapa lulusan S1 dari universitas terbuka yangmana mereka dulunya kuliah sambil bekerja. Karena keterbatasan ekonomi dan lingkungan tempat tinggal yang di desa inilah yang menjadikan mereka kekurangan literasi terhadap keberadaan lembaga keuangan syariah. Hal ini terlihat dari masih rendahnya minat peserta untuk melakukan transaksi di lembaga keuangan syariah. Usia peserta yang tergolong milenial ini diharapkan dapat memiliki pemahaman yang luas terhadap industri keuangan syariah dan dapat menjadi penggerak untuk kemudian mensosialisasikan ke teman kerja, kerabat dan lingkungan peserta. Berdasarkan penjelasan tersebut, maka permasalahan pada masyarakat Desa Honggosoco yang ingin ditangani melalui pengabdian ini adalah peningkatan literasi lembaga keuangan syariah masyarakat pada anggota fatayat NU agar nantinya dapat menambah Inklusi keuangan Syariah di Indonesia.

\section{METODE}

Pelaksanaan kegiatan pengabdian kepada masyarakat ini dilakukan dengan menggunakan metode ceramah, simulasi, dan diskusi. Semua kegiatan tersebut dilaksanakan secara daring oleh tim pengabdian dikarenakan kondisi lingkungan di Kota Kudus yang masih belum aman dan diperbolehkan untuk melakukan pengumpulan orang untuk upaya membantu pemerintah dalam mengurangi penyebaran virus Corona yang saat ini sedang dialami di Indonesia. Kondisi tersebut membuat tim pengabdian menggunakan cara lain dalam melaksanakan program/kegiatan yaitu dengan cara online melalui grup whatsapps Fatayat NU Desa Honggosoco. Aplikasi Whatsapps ini dipilih karena dianggap paling mudah untuk bisa diikuti oleh semua anggota Fatayat NU yang kebanyakan adalah Ibu-ibu muda. Kegiatan pengabdian kepada masyarakat dilakukan dengan metode ceramah, simulasi, dan diskusi.

Adapun penjelasan dari metode yang digunakan dalam proses pelatihan dan 
pendampingan kegiatan penngabdian ini adalah sebagai beirkut :

1. Ceramah

Peserta diberikan pengetahuan mengenai jenis lembaga keuangan yang ada di Indonesia, perbedaan antara bank syariah dan bank konvensional dan produk serta jasa yang ada di Bank Syariah yang disampaikan oleh masing-masing anggota tim pengabdian.

2. Simulasi

Peserta diberikan gambaran simulasi melakukan transaksi keuangan seperti tabungan dengan menggunakan pilihan akad yang tersedia di Bank Syariah yaitu akad wadiah dan akad mudharabah. Selanjutnya peserta akan dapat melihat perbedaan dari dua hasil transaksi yang telah dilakukan. Perbedaan yang muncul dapat dilihat dari nilai uang yang diperoleh di akhir oleh peserta. Dari simulasi ini peserta menjadi mengerti perbedaan dan alur sistem dari produk yang ada di Bank Syariah.

3. Diskusi

Diskusi dilakukan setelah pemaparan materi dan pemberian simulasi selesai dilakukan. Diskusi dilakukan untuk menjawab pertanyaan yang bertujuan untuk mengetahui pemahaman peserta tentang materi yang telah diberikan.

\section{HASIL DAN PEMBAHASAN}

Pengabdian ini dilaksanakan di Desa Honggosoco Kecamatan Jekulo Kabupaten Kudus kepada anggota Fatayat NU di desa tersebut. Terdapat lima tahapan dalam pelaksanaan kegiatan tersebut. Adapun kegiatan yang dilakukan pada setiap tahapan adalah sebagai berikut:

\section{Tahap Perencanaan Kegiatan}

Pada tahap perencanaan, tim pengabdian membuat rencana dan rancangan dengan melakukan kegiatan sebagai berikut:

a. Studi lapangan dan menganalisis situasi di lingkungan Desa Honggosoco Kecamatan Jekulo Kabupaten Kudus b. Menganalisa permasaahan apa yang terjadi pada masyarakat Desa Honggosoco Kecamatan Jekulo Kabupaten Kudus

c. Berkoordinasi dan konsultasi dengan masyarakat dan ketua organisasi di desa tersebut.

d. Pengumpulan sumber rujukan dan studi literatur tentang Lembaga Keuangan Syariah di Indonesia untuk meningkatkan literasi keuangan masyarakat

e. Mempersiapkan materi yang akan disampaikan kepada anggota Fatayat NU di Desa Honggosoco Kecamatan Jekulo Kabupaten Kudus

\section{Tahap Pelaksanaan}

Pada tahap pelaksanaan ini, tim pengabdian memberikan pelatihan dan pendampingan dalam beberapa tahapan yang dilaksanakan secara daring melalui grup Whatsapps Fatayat NU Desa Honggosoco, yaitu sebagai berikut:

a. Pemaparan materi mengenai jenis-jenis lembaga keuangan syariah yang ada di Indonesia, konsep bank syariah dan perbedaaanya dengan bank konvensional, serta penjelasan tentang produk dan jasa yang ditawarkan di bank syariah. Pemaparan dilakukan dengan cara tim pengabdian membuat rekaman video penjelasan materi tersebut yang kemudian diupload di youtube dan dapat dibuka melalui alamat link : https://youtu.be/jVGDplaCLXs. Link inilah yang selanjutnya dibagikan kepada anggota Fatayat NU Desa Honggosoco melalui grup whatsapps.

\section{Tahap Simulasi}

Pada tahap simulasi ini peserta diberikan penjelasan simulasi menabung di Bank Syariah dengan menggunakan dua jenis akad yang berbeda yaitu akad wadiah dan akad mudharabah. Simulasi ini disampaikan melalui poster yang telah dibuat oleh tim pengabdian dan dibagikan di grup whatsapps Fatayat NU Desa Honggosoco.

\section{Tahap Follow Up Kegiatan Pelatihan.}

Tahap ini dilakukan dalam bentuk sesi kegiatan tanya jawab dan diskusi antara peserta 
dengan pemateri. Dalam kegiatan ini, peserta diberi kesempatan untuk bertanya dan memberikan tanggapan terhadap materi lembaga keuangan syariah yang telah dijelaskan oleh pemateri. Pemateri dalam hal ini tim pengabdian menjawab berbagai pertanyaan dan tanggapan yang telah diberikan oleh peserta yang hadir dalam kegiatan pengabdian di grup Whatsapps.

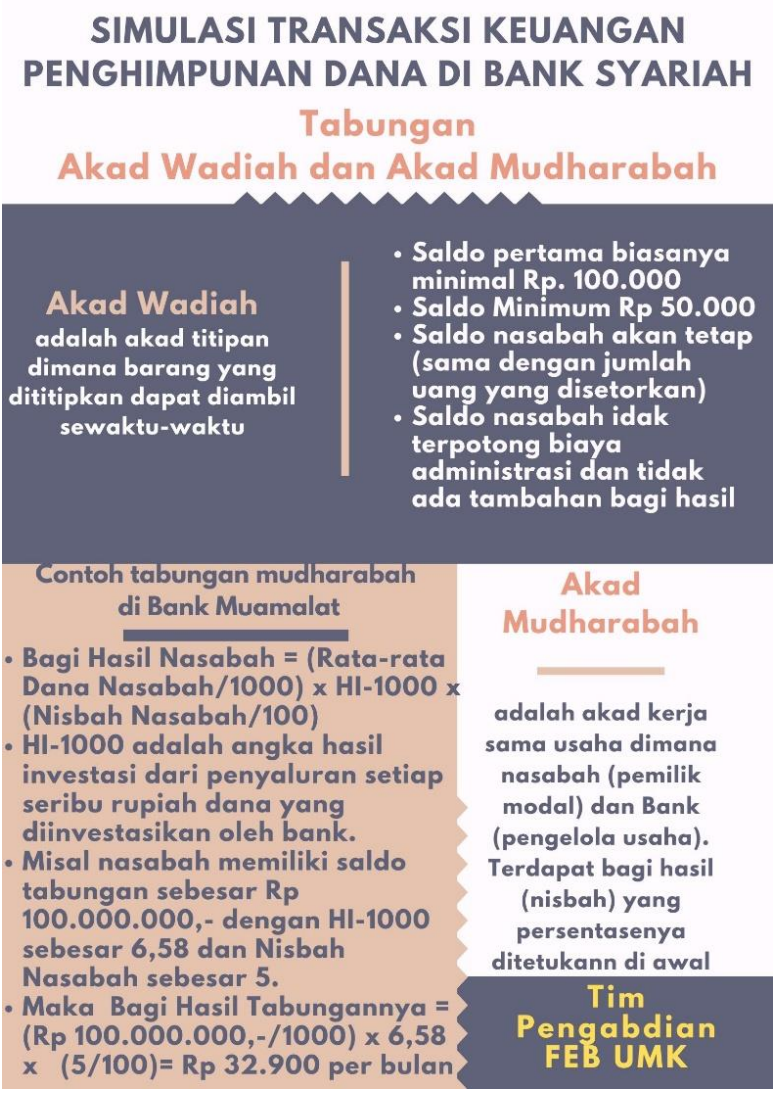

Gambar 1. Simulasi tabungan akad wadiah dan akad mudharabah di Bank Syariah

\section{Tahap Evaluasi Kegiatan}

Tim pengabdian melakukan kegiatan evaluasi, menilai, memberi saran, masukan dan penghargaan terkait hasil pelatihan, simulasi dan kegiatan pelatihan peningkatan literasi keuangan lembaga syariah di Indonesia kepada anggota Fatayat NU Desa Honggosoco Kecamatan Jekulo Kabupaten Kudus.

Evaluasi dilakukan dengan cara menanyakan langsung kepada peserta tentang kritik dan saran setelah pelatihan dilakukan untuk mengetahui efektifitas dan manfaat yang dirasakan oleh peserta pelatihan. Dari hasil evaluasi diperoleh bahwa kegiatan pelatihan peningkatan literasi keuangan lembaga syariah di Indonesia kepada anggota Fatayat NU Desa Honggosoco Kecamatan Jekulo Kabupaten Kudus berjalan dengan lancar dan efektif. Hal ini terlihat dari keaktifan peserta dalam mengikuti tahapan kegiatan pengabdian dari awal sampai akhir yang terlihat dari jumlah kehadiran di grup Whatsapps dan jumlah views di video youtube. Selain itu peserta juga berharap bahwa kegiatan pengabdian ini dapat terus dilaksanakan dengan topik selanjutnya yang bermanfaat untuk meningkatkan literasi masyarakat di bidang yang lainnya.

\section{PENUTUP \\ Kesimpulan}

Pemahaman tentang materi lembaga keuangan syariah pada Ibu-ibu anggota Fatayat NU Desa Honggosoco Kecamatan Jekulo Kabupaten Kudus masih sangat rendah sehingga perlu diberikan tambahan edukasi agar dapat meningkatkan literasi lembaga keuangan syariah pada masyarakat. Melalui program pengabdian ini, tim berusaha untuk memberikan penjelasan serta pemahaman yang benar tentang jenis-jenis lembaga keuangan syariah yang ada di Indonesia saat ini dan juga bagaimana sistem dari bank syariah dan perbedaannya dengan bank konvensional. Selain itu tim pengabdian juga memberikan gambaran produk dan jasa yang ada di Bank Syariah serta simulasi tabungan dengan pilihan akad yang berbeda agar dapat mudah dipahami oleh anggota fatayat NU.

Anggota Fatayat NU yang terdiri dari para Ibu muda ini memiliki semangat yang tinggi dalam mempelajari hal baru dan merupakan peserta yang tepat untuk dapat menerima edukasi dari tim pengabdian kepada masyarakat. Hal ini karena selain kebanyakan anggota sudah memiliki penghasilan sendiri, mereka juga merupakan pengelola keuangan di dalam sebuah keluarga atau rumah tangga, sehingga membutuhkan pemahaman yang benar terhadap produk yang ditawarkan di lembaga keuangan syariah. Pemahaman yang baik inilah yang diharapkan oleh tim pengabdian agar masyarakat teredukasi dalam memanfaatkan produk dan jasa di lembaga keuangan secara benar dan bijak serta terhindar 
dari unsur penipuan yang kerap terjadi di Indonesia.

\section{Saran}

Kegiatan program pengabdian ini memiliki beberapa keterbatasan. Pertama adalah dari segi pelaksanaannya yang harus dilakukan secara daring melalui grup Whatsapps menjadikan penyampaian materi kepada peserta kurang maksimal sehingga harapannya akan ada kesempatan lagi yang aman untuk dapat bertatap muka secara langsung. Kedua adalah keterbatasan waktu karena jadwal peserta yang berbeda-beda untuk dapat bersama-sama bergabung dalam pelaksanaan program pengabdian. Selanjutnya tim pengabdian berharap dapat melanjutkan kerja sama dalam berbagai program kegiatan lain yang dapat memberikan manfaat kepada masyarakat di Desa Honggosoco.

\section{DAFTAR PUSTAKA}

Anshori, Abdul Ghofur. 2018. Perbankan Syariah di Indonesia. Yogyakarta : Gadjah Mada University Press

Antonio, Muhammad Syafi'i. 2001. Bank Syariah dari Teori ke Praktek. Jakarta: Gema Insani

Munthe, Safaruddin. 2017. Implementasi Prinsip Ekonomi Syariah dalam Peraturan Perbankan Syariah sebagai Pencapaian dalam Hukum Islam. Jurnal Ilmiah “Advokasi”, Vol. 5, No. 1 (Maret 2017)

Musolin, Muhlil. 2016. Konsep Wadiah sebagai Produk Perbankan Syariah dalam Perspektif Fiqh Muamalah". An-Nawa: Jurnal Hukum Islam, Vol XVIII (JanuariJuni 2016)

Nofinawati. 2014 "Akad dan Produk Perbankan Syariah".Jurnal Fitrah, Vol. 8, No. 2 (Juli-Desember 2014), 219-220.

Rafsanjani, Haqiqi. 2016. "Akad Tabarru' dalam Transaksi Bisnis, Masyarif al-Syari'ah. Jurnal Perbankan Syariah, Vol. 1, No. 1 (Mei 2016)

Tim Pengembangan Perbankan Syariah Institut Bankir Indonesia. 2008. Konsep Produk dan Implementasi Operasional Bank Syariah .Jakarta: Djambatan

Warkum Sumitro. 1996. Asas-asas Perbankan
Islam dan Lembaga Terkait. Jakarta: PT. Raja Grafindo Persada 